On the other hand, subscriptions to the journal are expensive (especially for six issues a year) and raise the general issue of why anyone would want to subscribe to this or any other journal in the field? They are merely expensive archival collections of solid research articles, most of which any one reader will not be interested in. Neuroendocrinology has probably reached the stage where an intellectual focus would be welcome and useful, a place for book reviews, and mini-research reviews,

\section{More of less?}

\section{Peter Sheterline}

Seminars in Cell Biology. Guest editors. Saunders. 6/yr. US and Canada \$120, elsewhere $\$ 140$ (institutional); US and Canada $\$ 75$, elsewhere $\$ 95$ (personal); US and Canada $\$ 60$, elsewhere $\$ 80$ (students).

Cell Regulation. Editor-in-chief Erkki Ruoslahti. The American Society for Cell Biology. 12/yr. $\$ 300$ (institutional), $\$ 200$ (personal), $\$ 130$ (members), $\$ 90$ (student members).

As a result of some devious logic, I have received two very different types of journal to review contiguously. Both are aimed at cell biologists and both highlight some of the important issues surrounding scientific publishing. Seminars in Cell Biology is another venue for reviews of topics of interest to cell biologists. Not so long ago there was something of a dearth of readable, affordable overview journals covering the main systems in cell biology. We needed them then as we do now, partly because the cell-biology view requires at least a nodding aquaintance with cellular bits other than those of direct research interest and a healthy respect for their interrelatedness; ask not for whom the calcium rises; it rises for thee, and partly because, by courtesy of molecular geneticists, the field was and is expanding very quickly. The cry for review material by cell biologists was clearly sufficiently loud to have been heard by almost every scientific publisher. There emerged, consequently, a clutch of cellbiology review journals.

Seminars in follows Annual Reviews in, Current Opinion in, Bioessays and Trends in. It appears bimonthly under a guest editor who assembles 5-8 authors to write on a particular topic (chosen by the editorial board?). Volume 1, which covered 1990, consisted of six issues devoted to, respectively: molecular chaperones; sensory adaptation and motor activation in chemotaxis; pattern formation in Drosophila; calcium homeostasis in muscle and nonmuscle along with more traditional reviews and original articles, and a place for only the most exciting, original work. Forgive me for repeating an oft-heard sentiment, but the trail blazed by Cell for molecular genetics should be followed or explored even further by other leading journals in other disciplines.

Larry $W$. Swanson is in the Department of Biological Sciences, University of Southern California, Los Angeles, Calfornia 900892520, USA.

cells (what other kinds of cells are there?); membrane cytoskeleton in development (I bet you hadn't thought of that one); and pathways of intracellular proteolysis. There appears to be a fairly loose remit on style and content imposed on both editor and authors. The papers themselves are fairly short (5-10 pages) and are conventional short reviews of recent data. As with any such exercise,

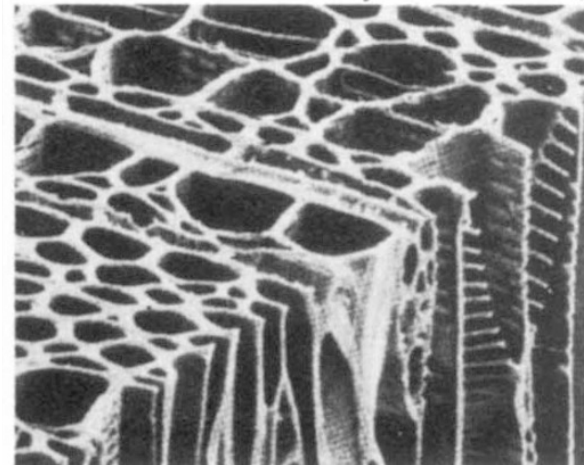

SEM of cut surface of wood $(\times 5,200)$. In 1665, Robert Hooke termed similar microscopic units of cork 'cells'. (From Molecular Cell Biology by J. Darnell et al., published by Scientific American Books.)

some of the topics are covered very well, some not so well. There is no attempt to provide a complete reference list, but the references are relatively up-to-date; the first 1990 references, for example appeared in the August 1990 issue.

The journal is very conventional in comparison with the highly structured approach of the Current Opinion series, one of its direct competitors. Current Opinion volumes contain a relatively complete annual bibliography in identified topic areas and a promise to revisit sites of scientific interest annually. In my view, the Current Opinion series, although far from perfect, heralds a welcome new professional relationship between publisher and scientist who collaborate to produce a valuable resource. Seminars is not hampered by any such objectives, nor by the commitment to cover key topics annually. On balance, I do not think that the journal offers anything that is either particularly well conceived or executed and I cannot see why many scientists would wish to commit their scarce funds to a review journal whose content is entirely unpredictable, as can be seen from the 1990 issues. It is just another publication to add to the burgeoning list that uses the energies and resources of both authors and publishers to no great effect.

Cell Regulation is a strictly research publication dedicated to this field. I cannot think off-hand of many things in cells that do not involve regulation, so the title has neither restricted the scope of papers that can be submitted to the journal nor defined a clear area for afficionados. It is a well-produced journal of the Cell ilk, but contains papers that are more reminiscent of the Journal of Cell Biology. One can't help thinking of it as simply 'Son of $J C B$ '.

The papers are of high quality, and, according to the blurb, the journal uses "an innovative routing system for manuscripts" (completely eliminating referees?) to allow publication of papers submitted by the beginning of one month to be published in the issue four months on. Not bad, but not unique. A quick check on whether the promises were sustained by the actuality revealed that, generally, they were. In the December 1990 issue, for example, all papers were submitted between 28 July and 6 September, most being submitted in August. There are about seven papers per issue, which makes me wonder why the American Society for Cell Biology does not simply increase the size of the Journal of Cell Biology by a few per cent and save some trees. I cannot see why libraries or individuals should rush out and buy Cell Regulation, which would seem to be an unnecessary clone of its parent.

How do scientists and libraries best exert customer pressure on publishers and potential journal editors? Most libraries cannot now afford to continue complete sets of all cell-biology journals, let alone life-science journals; it is important, therefore, that libraries establish well-thought-out systems for rigorously assessing journal quality and usage, and adapt their subscriptions accordingly. In some senses, the more ruthless the libraries' quality assessments, the more pressure there will be on publishers to consider more carefully their objectives. There is not much dissention over which are the valuable core journals; these are ultimately the result of who publishes what in them (as it should be). Cell Regulation may well flourish because of its heavyweight patron. Perhaps the entrance to all publishing offices should be inscribed "Less but better", as should those of the funding bodies, whose insatiable paper-lust probably drives the entire machine.

Peter Sheterline is in the Department of Human Anatomy and Cell Biology, University of Liverpool, Liverpool L69 3BX, UK. 